\title{
EFFECTS OF UNEXTRUDED AND EXTRUDED CRANBERRY POMACE ON SELECTED METABOLIC PARAMETERS IN HIGH-FAT DIET FED RATS*
}

\author{
Joanna Bajerska ${ }^{1 凶}$, Agata Chmurzynska ${ }^{1}$, Sylwia Mildner-Szkudlarz ${ }^{2}$, \\ Sławomira Drzymała-Czyż ${ }^{3}$, Paweł Górnaś4, Agnieszka Waśkiewicz \\ Agata Muzsik ${ }^{1}$, Tomasz Podgórski ${ }^{6}$, Paulina Nowaczyk ${ }^{1}$, Małgorzata Woźniewicz ${ }^{1}$
}

\author{
${ }^{1}$ Institute of Human Nutrition and Dietetics, Poznań University of Life Sciences \\ Wojska Polskiego 31, 60-624 Poznań, Poland \\ ${ }^{2}$ Institute of Food Technology of Plant Origin, Poznań University of Life Sciences \\ Wojska Polskiego 31, 60-624 Poznań, Poland \\ ${ }^{3}$ Department of Pediatric Gastroenterology and Metabolism, Poznan University of Medical Sciences \\ Szpitalna 27/33, 60-572 Poznań, Poland \\ ${ }^{4}$ Institute of Horticulture, Latvia University of Agriculture \\ Graudu 1, Dobele, LV-3701, Latvia \\ ${ }^{5}$ Department of Chemistry, Poznań University of Life Sciences \\ Wojska Polskiego 75, 60-625 Poznań, Poland \\ ${ }^{6}$ Department of Biochemistry, University School of Physical Education \\ Królowej Jadwigi 27/39, 61-871 Poznań, Poland
}

\begin{abstract}
Aim. The effects of un-extruded (UCP) and extruded cranberry pomace (ECP) on fecal fat excretion, liver index, lipid and carbohydrate metabolism, and inhibition of oxidative stress due to a high-fat diet (HFD) in rats were studied.

Material and methods. The Wistar rats for 8 weeks received one of the four diets: (1) control (modified the American Institute of Nutrition: AIN based diet containing 7\% fat), (2) HFD (AIN based diet containing 30\% fat), (3) HFD with 3\% un-extruded (UCP) and (4) HFD with 3\% (ECP).

Result. Both UCP and ECP significantly improved the plasma antioxidant capacity and decreased lipid peroxidation in rats fed a HFD. However, only the addition of 3\% UCP into the HFD significantly increased the fecal lipid excretion and considerably decreased serum triglycerides level in rats.

Conclusion. Further investigation is needed to determine the role of an individual components present in UCP and ECP in the improvement of metabolic conditions observed in the current study.
\end{abstract}

Keywords: cranberry pomace, extrusion, high-fat diet, metabolic parameters, rats

\footnotetext{
* This research was financed by the Ministry of Science and Higher Education (Poland) for young scientists.
} 


\section{INTRODUCTION}

A number of studies have found an inverse relation between a sufficient intake of fruits high in phytochemical compounds and the risk of chronic diseases (Blumberg et al., 2013; Hung et al., 2004; Kim et al., 2013). However, there is not enough information to make specific recommendations for phytochemical intake (Slavin, 2012). Cranberry contains a relatively high level of phytochemicals, which have been studied extensively for their ability to reduce the onset and symptoms of urinary tract infections, inflammation, and cancer (Khanal, 2010; Pappas and Schaich, 2009). They are now fast becoming a subject of intense research in regards to their role in promoting cardiovascular health (Khanal, 2010; Pappas and Schaich, 2009). Cranberry pomace (CP) is a by-product of the cranberry-processing industry and is composed of the skin, seeds, and stems (White et al., 2010b). Due to low protein content, the applications of $\mathrm{CP}$ for animal feeds are limited (Blumberg et al., 2013). Since the CP still contains a high level of phenolic compounds, tocochromanols and dietary fiber, this by-product can be however use to fortify commonly consumed foodstuffs that have little nutritional value - for instance, muffins (Mildner-Szkudlarz et al., 2016) and extruded snacks (Khanal, 2010; Roopchand et al., 2013). This manipulation can significantly improve the nutritional value of these food items and ultimately the nutritional status of the population. However, the influence of food processing (including of the extrusion process) on the quantity and activity of CP phytochemicals and their antioxidant activity in the final food products and associated with this health benefits should be also taken into consideration. Although the primary function of food is to provide nutrients, its secondary function involves sensory attributes such as taste and flavour. In general, cranberries have a tart and astringent taste, which has a strong influence on the taste and flavour of food items it enriches, even at low substitution levels (Blumberg et al., 2013). The use of cranberry bioactives as functional food components is thus limited. According to White et al. (2010a) 30:70 ratio of CP to corn starch is desirable in producing well-accepted cranberry extrudates. Therefore, in the present study, extruded (ECP) and un-extruded cranberry pomace (UCP) were included into a high-fat diet (HDF) at dose of $3 \%$ to determine their effectiveness on fecal excretion of total fat, liver index, lipid and carbohydrate metabolism, and inhibition of oxidative damage due to a high-fat diet in Wistar rats.

\section{MATERIAL AND METHODS}

\section{Sample preparation}

Cranberry pomace (CP) deriving from the 2013 crop of cranberries (Vaccinium macrocarpon) was provided by a juice producer in Poland (Polska Róża Ernest Michalski, Raszyn, Poland). The material was lyophilised under vacuum (Martin Christ-Alpha 1-4 freeze drier, Osterode am Harz, Germany). The composition of dried CP is presented in Table 1 .

Table 1. The composition of dried CP

\begin{tabular}{lc}
\hline \multicolumn{1}{c}{ Components } & $\begin{array}{c}\text { Content in } 100 \mathrm{~g} \\
\text { of CP sample, } \mathrm{g}\end{array}$ \\
\hline Ash & $1.0 \pm 0.04$ \\
Protein & $2.0 \pm 0.06$ \\
Total fat & $10.5 \pm 0.14$ \\
Insoluble fibre & $67.3 \pm 2.6$ \\
Soluble fibre & $5.7 \pm 0.1$ \\
Other carbohydrates & \\
$\quad-$ glucose & $6.7 \pm 0.11$ \\
$\quad$ fructose & $1.9 \pm 0.05$ \\
\hline
\end{tabular}

Values are means \pm SDs of three replicates.

\section{Extrusion}

For extrusion, the $\mathrm{CP}$ was mixed with cornstarch ("Stanisław Grygier Mill", Śmigiel, Poland) in an industrial kitchen mixture (Mesko-AGD, Skarżysko) at a 30:70 ratio of $\mathrm{CP}$ to cornstarch on a dry-weight basis (a total of $2 \mathrm{~kg} / \mathrm{bath}$ ). This ratio was taken into account when calculating the level of CP in the diet during the diet formulation for both ECP and UCP. The raw materials were brought to a moisture content of $14 \%$ by adding the appropriate amount of water, mixing, and resting for $1 \mathrm{~h}$. The extrusion of the CP mixture was carried out using an S-54 single screw 
extruder (Metalchem Gliwice, Poland). The following process parameters were applied: the temperature at individual zones of $135^{\circ} \mathrm{C} / 175^{\circ} \mathrm{C} / 135^{\circ} \mathrm{C}$, screw rotations at $120 \mathrm{rpm}$ and a nozzle diameter of $3.0 \mathrm{~mm}$. Extrudates were allowed to cool, placed in sealed bags, and stored at $-20^{\circ} \mathrm{C}$ for chemical analysis.

\section{Tocochromanol (lipophilic antioxidants) determination}

Tocochromanols were extracted in accordance with a previously developed method described by Górnaś et al. (2014a) and determined by RP-HPLC, according to an earlier validated method (Górnaś et al., 2014b).

\section{Phenolic compounds (hydrophilic antioxidants) determination}

The phenolic compounds were extracted from the defatted pomace and extrudates using a method described by Makarova et al. (2015) and determined using a Shimadzu HPLC system (Kyoto, Japan).

\section{Evaluation of antioxidant capacity}

Both fractions of antioxidants - the lipophilic (tocopherols and tocotrienols) and hydrophilic (polyphenols) - were combined, according to the sample weight for the extraction, and diluted by ethanol to obtain concentrations in the range of the developed calibration curves for the antioxidant assay.

\section{DPPH`assay}

The DPPH ${ }^{\circ}$ assay was performed by a previously developed method (Górnaś et al., 2015).

\section{Animal experiment}

The animal study design was approved by the local bioethics committee on animal research at Poznań University of Life Sciences (approval 68/2010, 3 September 2010). 40 male Wistar rats (56 days old) were housed on a 12-h dark/12-h light cycle, at a temperature of $22^{\circ} \pm 2^{\circ} \mathrm{C}$. After one week of acclimatization the animals were randomly divided into four groups ( $n=10$ each) with equal average body weight and fed: (1) control (modified AIN based diet containing $7 \%$ fat), (2) high fat diet (AIN based diet containing $30 \%$ fat, HFD), (3) HFD with 3\% un-extruded cranberry pomace (UCP-HFD) and (4) HFD with $3 \%$ extruded cranberry pomace (ECP-HFD) for 8 weeks with ad libitum access to tap water and diet. The diets were freshly prepared at weekly intervals, stored in hermetic containers at $-20^{\circ} \mathrm{C}$. The composition of the animal diets is presented in Table 2. The food intake of the individual rats was checked every day by measuring the difference between the amount of diet supplied each day and the amount of diet remaining. Body mass was measured every seven days using an electronic balance. Feces were collected quantitatively from individual rats during the last 7 days of the eighth-period and dried for later analysis. At the end of the experiment, and after overnight fasting, the animals were euthanized by intraperitoneal injection of ketamine-xylazine. Blood was collected by cardiac puncture for future biochemical studies. The liver was dissected and weighted.

\section{Macronutrient analysis of $\mathrm{CP}$, diets and feces}

Gross energy of the diet was measured by bomb calorimetry (Calorimeter KL-11 Mikado Microprocessor System, Precyzja, Bydgoszcz, Poland). Moisture and ash in CP were assessed according to standards procedures. Nitrogen in the total $\mathrm{CP}$ and in the animal diets was determined with the Kjeldahl method using a Tecator-Kjeltec system 1026 (Tecator AB, Höganäs, Sweden). To calculate the amount of protein in the evaluated samples, the results were multiplied by 6.25. Fat contents in the $\mathrm{CP}$, animal diets and faeces were measured by extracting $5 \mathrm{~g}$ of each sample with petroleum ether in a Soxtec Avanti 2055 apparatus (Foss Tecator AB). The amounts of total dietary fibre (TDF), soluble dietary fibre (SDF), and insoluble dietary fibre (IDF) in the CP samples were established by an enzyme-gravimetric method described by Asp et al. (1983).

\section{Blood biochemical analysis}

The levels of total cholesterol (TC), and triglycerides (TG) were determined using an automatic biochemical Olympus AU 560 analyser (Olympus Japan, Tokyo, Japan). Fasting glucose (GLU) concentrations were measured using the hexokinase method (Olympus AU 2700). Insulin (INS) levels were measured with specific radioimmunoassay Rat Insulin RIA Kit RI-13K (Millipore Corporation, St. Charles, MO, USA) according to the manufacturer's protocol. $\beta$-cell function (HOMA-BCF) was calculated as 20·FPI/(FPG-3.5). 
Table 2. Experimental diets composition per $1000 \mathrm{~g}$ of diet

\begin{tabular}{|c|c|c|c|c|}
\hline \multirow{2}{*}{ Ingredients } & \multicolumn{4}{|c|}{ Diets } \\
\hline & control & HFD & $3 \%$ UCP-HFD & $3 \%$ ECP-HFD \\
\hline Casein & 120 & 120 & 120 & 120 \\
\hline Sucrose & 100 & 100 & 97.1 & 97.1 \\
\hline Sunflower oil & 70 & 100 & 100 & 100 \\
\hline Lard & 0 & 200 & 200 & 200 \\
\hline Cellulose & 50 & 50 & 25 & 25 \\
\hline Cornstarch & 612 & 382 & 309.9 & 309.9 \\
\hline L-cysteine & 3 & 3 & 3 & 3 \\
\hline AIN 93 vitamin mix & 10 & 10 & 10 & 10 \\
\hline AIN 93 mineral mix & 35 & 35 & 35 & 35 \\
\hline $\mathrm{UCP}$ & 0 & 0 & 100 & 0 \\
\hline $\mathrm{ECP}$ & 0 & 0 & 0 & 100 \\
\hline Total & 1000 & 1000 & 1000 & 1000 \\
\hline Energy, kcal/100 g & 417.1 & 530.9 & 532.3 & 531.8 \\
\hline$\%$ energy from protein & 13.0 & 11.0 & 11.0 & 11.0 \\
\hline$\%$ energy from fat & 15.0 & 51.0 & 51.0 & 51.0 \\
\hline$\%$ energy from carbohydrate & 72.0 & 38.0 & 38.0 & 38.0 \\
\hline
\end{tabular}

UCP - un-extruded cranberry pomace, ECP - extruded cranberry pomace, HFD - high-fat diet, UCP-HFD - high-fat diet enriched with $3 \%$ unextruded cranberry pomace, ECP-HFD - high-fat diet enriched with $3 \%$ extruded cranberry pomace.

The homocysteine (Hcy) and glutathione (GSH) concentrations were measured using HPLC, according to the method of Chmurzynska et al. (2013). Chemical antioxidants presented in rat plasma were examined using ferric reducing ability (FRAP) methodology elaborated by Benzie and Strain (1996). As a marker of lipid peroxidation products, ThioBarbituric Acid Reactive Substances (TBARS) concentration was measured using the method of Ohkawa et al. (1979).

\section{Statistical analysis}

Data are presented as means, standard deviation (SD), or standard errors (SEM) where appropriate. The normality of data and homogeneity of variances were tested using the Shapiro-Wilk test. The significance of differences among the groups was assessed using one-way analysis of variance and Tukey's posthoc test or a non-parametric Kruskal-Wallis test. Statistical significance was assumed for $p<0.05$ (Statistica 10.0 software, StatSoft, Kraków, Poland).

\section{RESULTS AND DISCUSSION}

\section{Effect of extrusion process}

on the phenolic and lipophilic antioxidant compound contents of UCP and ECP

The total flavonol content of ECP was almost eight times lower than that of UCP, whereas anthocyanins were found only in UCP (Table 3 ). While by Khanal et al. (2010) and White et al. (2010a), higher levels of total flavonols after the extrusion process were reported. The difference between the present study and study mentioned above (White et al., 2010a) may be the result of applied different parameters during extrusion process 
Bajerska, J., Chmurzynska, A., Mildner-Szkudlarz, S., Drzymała-Czyż, S., Górnaś, P., Waśkiewicz, A., Muzsik, A., Podgórski, T., Nowaczyk, P., Woźniewicz, M. (2018). Effects of unextruded and extruded cranberry pomace on selected metabolic parameters in high-fat diet fed rats. Acta Sci. Pol. Technol. Aliment., 17(1), 91-100. http://dx.doi.org/10.17306/J.AFS.2018.0542

Table 3. Content of hydrophilic and lipophilic antioxidants of UCP and ECP with their antioxidant potentials (DPPH' assay), $\mathrm{mg} / 100 \mathrm{~g}$

\begin{tabular}{lcl}
\hline \multicolumn{1}{c}{ Components } & $\mathrm{UCP}$ & $\mathrm{ECP}$ \\
\hline Cyanidin 3- $O$-galactoside & $5.2 \pm 0.1$ & $\mathrm{ND}$ \\
Cyanidin 3- $O$-arabinoside & $5.6 \pm 0.2$ & $\mathrm{ND}$ \\
Peonidin 3- $O$-galactoside & $8.3 \pm 0.2$ & $\mathrm{ND}$ \\
Peonidin 3- $O$-glucoside & $4.8 \pm 0.01$ & $\mathrm{ND}$ \\
Peonidin 3- $O$-arabinoside & $8.1 \pm 0.04$ & $\mathrm{ND}$ \\
\hline Total anthocyanins & $32.1 \pm 0.5$ & - \\
\hline Myricetin 3- $O$-galactoside & $4.1 \pm 0.2$ & $0.3 \pm 0.03$ \\
Myricetin 3- $O$-arabinoside & $6.1 \pm 0.2$ & $0.2 \pm 0.04$ \\
Myricetin & $12.1 \pm 0.3$ & $1.5 \pm 0.10$ \\
Quercetin & $23.6 \pm 0.5$ & $4.0 \pm 0.15$ \\
Quercetin 3- $O$-benzoyl galactoside & $4.6 \pm 0.2$ & $0.3 \pm 0.02$ \\
Quercetin 3- $O$-rhamnoside & $8.3 \pm 0.1$ & $1.2 \pm 0.02$ \\
\hline Total flavonols & $58.7 \pm 1.5$ & $7.5 \pm 0.43$ \\
\hline$\delta$-T3 & $0.5 \pm 0.01$ & $0.6 \pm 0.03$ \\
$\gamma$-T3 & $4.7 \pm 0.1$ & $1.6 \pm 0.2$ \\
$\alpha$-T3 & $0.9 \pm 0.1$ & $0.6 \pm 0.03$ \\
$\alpha$-T & $0.3 \pm 0.02$ & $0.1 \pm 0.01$ \\
\hline Total tocochromanols & $0.3 \pm 0.02$ & $0.6 \pm 0.01$ \\
\hline DPPH• assay, $\mu$ g GAE & $1.8 \pm 0.1$ & $2.4 \pm 0.2$ \\
\hline & $8.7 \pm 0.1$ & \\
\hline & $17.2 \pm 0.5$ & 0.3 \\
\hline
\end{tabular}

Values are means \pm SDs of three replicates. ND - not detected, ECP - extruded cranberry pomace, UCP - unextruded cranberry pomace, $\mathrm{DPPH}^{\cdot}$ - assays measure antioxidant capacity using 1,1-diphenyl-2-picrylhydrazyl ( $\left.\mathrm{DPPH}^{\cdot}\right)$ free radicals.

between studies, as well as the bio composition of the raw material. The observed reduction of anthocyanin levels in the extruded product is related to the negative impact of high temperature. It was reported previously that content of anthocyanins is considerably reduced by heat treatment and depend on the time and temperature of the process (Górnaś et al., 2016; Mildner-Szkudlarz et al., 2016). Since the CP contains seeds, which are a valuable source of lipophilic antioxidants such as tocopherols and tocotrienols, the levels of these bioactive compounds were determined in both UCP and ECP samples. The total tocopherol and tocotrienol contents of ECP were three times lower than those of UCP. A significant reduction in tocochromanols during heat treatment has also been observed in muffins enriched with CP (Mildner-Szkudlarz et al., 2016). 
Although the content of hydrophilic and lipophilic antioxidants in ECP was lower than in UCP, the DPPH-scavenging activity of the tested samples was similar, at $7.1 \pm 0.1$ and $6.5 \pm 0.8 \mu \mathrm{g} \mathrm{GAE} / 100 \mathrm{mg}$ in UCP and ECP, respectively (Table 3 ). These results can be explained by the impact of Maillard reaction products in the extrudates. It is widely accepted that those products influence the antioxidant activity of foods, but only the soluble fraction - high molecular weight melanoidins and low molecular weight heterocyclic compounds contribute to the reducing power (Biller and Ekielski, 2015; Sharma et al., 2012).

\section{Effect of UCP and ECP on food intake, body weight, liver weight, and total fecal fat excretion in rats fed a HFD}

A significantly higher $(P<0.05)$ food intake was noted in the control group than in the other groups (Table 4). This higher food intake was observed because this diet has a lower energy density than any of the HFDs (Table 2). There was no signicicantly difference in body mass between the groups before and after the experiment, though we can observed tendency to decreased body weight gain by $6.7 \%$ in $3 \%$ UCP HDF as compared with control HFD group. Incorporation of HDF led to significant increase of liver index, however only the introduction of the UCP into the basal HFD significantly affected this index. All the HFD fed groups of rats had higher percentages of faecal fat content than the rats from the control group $(P<0.05)$. However, only the addition of UCP into the HFD significantly increased the faecal lipid excretion as compared with rats fed the HFD (Table 4). It seems that the differences observed can be explained by the presence of phytochemicals in UCP. For example, Martin-Carron et al. (1997) fed male Wistar rats a standard diet supplemented with $10 \%$ grape pomace over an eightweek period. The rats showed higher faecal weight as well as increased fat and protein excretion in the faeces than rats fed a control diet. Mildner-Szkudlarz and Bajerska (2013) also observed that a diet based on wheat bread enriched with dried powdered skins of grape by-products, or with freeze-dried extract of these, significantly increased faecal fat in rats, decreasing the apparent digestion of fat compared with a control HFD and a HFD enriched with control bread. Takahashi et al. (2014) indicated that anthocyanin-rich phytochemicals in chokeberry fruits significantly inhibited pancreatic lipase activity, hence reducing lipid absorption and enhancing fat excretion in faeces.

Red cabbage, which is rich in anthocyanin, can stimulate increased faecal lipid excretion and prevent elevation of serum and tissue lipids which is induced by atherogenic diet (Mohamed, 2014). Yet it is not only that phytochemicals can affect intestinal lipid absorption. In this terms, the changing in the ratio of insoluble to soluble fibre due to extrusion process should be also taken into consideration. Extrusion process decreases the IDF content and increases the SDF content in final products (Qian and Ding, 1996). The IDF causes

Table 4. Food intake, body weight, and liver weight in rats fed the control diet, an HFD, and HFDs enriched with UCP or ECP

\begin{tabular}{lcccc}
\hline \multicolumn{1}{c}{ Parameters } & \multicolumn{3}{c}{ Groups } \\
\cline { 2 - 5 } & control & HFD & $3 \%$ UCP-HFD & $3 \%$ ECP-HFD \\
\hline Food intake, g/d & $20.5 \pm 0.5^{\mathrm{b}}$ & $16.9 \pm 0.2^{\mathrm{a}}$ & $18.2 \pm 0.4^{\mathrm{a}}$ & $17.6 \pm 0.4^{\mathrm{a}}$ \\
Initial body weight, g & $217.1 \pm 9.4$ & $217.3 \pm 9.4$ & $217.8 \pm 8.8$ & $217.3 \pm 9.2$ \\
Final body weight, g & $456.5 \pm 12.3$ & $473.2 \pm 19.9$ & $456.6 \pm 11.6$ & $453.8 \pm 12.0$ \\
Liver weight, g/100 g BW & $2.5 \pm 0.06^{\mathrm{a}}$ & $2.8 \pm 0.08^{\mathrm{b}}$ & $2.5 \pm 0.07^{\mathrm{a}}$ & $2.6 \pm 0.05^{\mathrm{ab}}$ \\
Fecal lipids, \% dried feces & $2.7 \pm 0.2^{\mathrm{a}}$ & $3.8 \pm 0.1^{\mathrm{b}}$ & $4.3 \pm 0.1^{\mathrm{c}}$ & $4.0 \pm 0.2^{\mathrm{bc}}$ \\
\hline
\end{tabular}

Values are expressed as means $\pm \operatorname{SEM}(n=40)$. Values in the same row with different letters in superscript indicate significant differences at $P<0.05$. BW - body weight, $\mathrm{CP}$ - cranberry pomace, HFD - high-fat diet, 3\% HFD-UCP - high-fat diet enriched with $3 \%$ un-extruded cranberry pomace, $3 \%$ ECP-HFD - high-fat diet enriched with 3\% extruded cranberry pomace. 
Bajerska, J., Chmurzynska, A., Mildner-Szkudlarz, S., Drzymała-Czyż, S., Górnaś, P., Waśkiewicz, A., Muzsik, A., Podgórski, T., Nowaczyk, P., Woźniewicz, M. (2018). Effects of unextruded and extruded cranberry pomace on selected metabolic parameters in high-fat diet fed rats. Acta Sci. Pol. Technol. Aliment., 17(1), 91-100. http://dx.doi.org/10.17306/J.AFS.2018.0542

an increased rate of passage through the gastrointestinal tract and this results in reduced digestion and absorption of nutrients (Lattimer and Haub, 2010).

\section{Effects of UCP and ECP on lipid oxidation and antioxidant capacity of rats fed a HFD}

The incorporation of UCP or ECP into the HFDs significantly raised the plasma antioxidant capacities measured as FRAP and GSH (Table 5). The TBARS level, regarded as a marker of lipid peroxidation, was found to be elevated by the HF diet; however, the inclusion of either ECP or UCP to the HFD significantly decreased this parameter. This effect is in agreement with the study conducted by Kim et al. (2013) where $\mathrm{CP}$ was used. It was recognized that treatment with $5 \%$ of freeze-dried CP increased HDL cholesterol and reduced protein carbonyl, as well as TBARS levels, in rats fed an atherogenic diet (Kim et al., 2013). In the present study, the improvement in plasma antioxidant activity of the rats fed the HFD enriched with UCP was presumably due to the incorporation of compounds with strong antioxidant activity - mainly anthocyanins (cyanidin 3-O-galactoside) and flavonols (quercetin), but also lipophilic antioxidants such as tocopherols and tocotrienols. However, it should be mentioned that bioavailability of anthocyanins is usually low. The improvement of the antioxidant potential in rats fed the HFD enriched with ECP could be explained by the fact that the extrusion process mechanically disrupts cell walls of plants, improves the bioavailability of polyphenols (Singh et al., 2007). Gu et al. (2008) stated that procyanidins (especially the polymers) usually bind onto other macromolecules, such as fibre and protein. It is unclear how extrusion affects this binding, but it may degrade these macromolecules into smaller fragments and release bound procyanidins.

\section{Effects of ECP and UCP on metabolic parameters in rats fed a HFD}

It was pointed out that a rodent is generally accepted as a suitable lipid metabolic model for human (Buettner et al., 2006; Kobayashi et al., 2016). Lard is one of the most widely consumed foods rich in saturated fatty acids and it is often chosen in animal studies to test the deleterious effects of HFD. Levels of both TC and TG in serum from the HFD group of rats were significantly $(P<0.05)$ higher than those in control (Table 6). Administration 3\% UCP and 3\% ECP into the HFD had a tendency to decrease TC level. However, only $3 \%$ UCP-HFD group had significantly decreased levels of TG compared with control HFD. Neither the ECP nor the UCP significantly influenced either the Hcy level or the HOMA-BCF. In opposition to our findings, Khanal et al. (2010) indicated that ECP at a dose of $3 \%$ of the diet was more effective than UCP (given at the same level) in controlling the effects of high-fructose feeding. For instance, the inclusion of ECP, though not UCP, effectively lowered TC compared not only to the HFD but also to the starch-based diet. Similarly, Khanal et al. (2010) revealed that ECP was more effective in reducing the HOMA insulin resistance, TG, and insulin levels. Khanal et al. (2010) hypothesised that low molecular weight procyanidins found in ECP could be responsible for minimizing or

Table 5. Antioxidant capacity and lipid oxidation marker in rats fed the control diet, HFD, and HFDs enriched with UCP and ECP

\begin{tabular}{lcccc}
\hline \multirow{2}{*}{ Parameters } & \multicolumn{3}{c}{ Groups } \\
\cline { 2 - 5 } & \multicolumn{1}{c}{ control } & HFD & $3 \%$ UCP-HFD & $3 \%$ ECP-HFD \\
\hline FRAP, $\mu \mathrm{mol} \mathrm{FeII/L}$ & $377.7 \pm 12.5^{\mathrm{ab}}$ & $353.3 \pm 19.3^{\mathrm{a}}$ & $438.1 \pm 24.7^{\mathrm{b}}$ & $447.7 \pm 17.1^{\mathrm{b}}$ \\
GSH, $\mu \mathrm{mol} / \mathrm{L}$ & $41.1 \pm 3.2^{\mathrm{ab}}$ & $37.4 \pm 3.6^{\mathrm{a}}$ & $49.5 \pm 2.9^{\mathrm{b}}$ & $46.9 \pm 2.5^{\mathrm{b}}$ \\
TBARS, $\mu \mathrm{mol} \mathrm{MDA} / \mathrm{L}$ & $9.3 \pm 0.3^{\mathrm{ab}}$ & $10.1 \pm 0.2^{\mathrm{a}}$ & $8.8 \pm 0.2^{\mathrm{b}}$ & $8.4 \pm 0.4^{\mathrm{b}}$ \\
\hline
\end{tabular}

Values are expressed as means $\pm \operatorname{SEM}(n=40)$. Values in the same row with different letters in superscript indicate significant differences at $P<0.05$. FRAP - ferric-reducing ability of plasma, GSH - glutathione, TBARS - thiobarbituric-acid-reactive species, MDA - malondialdehyde, HFD - high-fat diet, 3\% UCP-HFD - high-fat diet enriched with 3\% unextruded cranberry pomace, $3 \%$ ECP-HFD - high-fat diet enriched with 3\% extruded cranberry pomace. 
Bajerska, J., Chmurzynska, A., Mildner-Szkudlarz, S., Drzymała-Czyż, S., Górnaś, P., Waśkiewicz, A., Muzsik, A., Podgórski, T., Nowaczyk, P., Woźniewicz, M. (2018). Effects of unextruded and extruded cranberry pomace on selected metabolic parameters in high-fat diet fed rats. Acta Sci. Pol. Technol. Aliment., 17(1), 91-100. http://dx.doi.org/10.17306/J.AFS.2018.0542

Table 6. The TC, TG, Hcy, and HOMA-BCF levels in rats fed the control diet, the HFD, and the HFDs enriched with UCP or ECP

\begin{tabular}{lcrcc}
\hline & \multicolumn{4}{c}{ Groups } \\
\cline { 2 - 5 } Parameters & control & HFD & $3 \%$ UCP-HFD & $3 \%$ ECP-HFD \\
\hline TC, mg/dL & $84.8 \pm 4.4^{\mathrm{a}}$ & $117.7 \pm 5.0^{\mathrm{b}}$ & $103.4 \pm 6.0^{\mathrm{ab}}$ & $103.2 \pm 4.0^{\mathrm{ab}}$ \\
$\mathrm{TG}, \mathrm{mg} / \mathrm{dL}$ & $56.8 \pm 3.9^{\mathrm{a}}$ & $102.3 \pm 5.2^{\mathrm{c}}$ & $70.2 \pm 4.6^{\mathrm{b}}$ & $87.4 \pm 4.3^{\mathrm{bc}}$ \\
Hcy, $\mu \mathrm{mol} / \mathrm{L}$ & $4.9 \pm 0.4$ & $5.7 \pm 0.3$ & $5.3 \pm 0.5$ & $5.3 \pm 0.4$ \\
HOMA-BCF & $106.2 \pm 21.9$ & $170.5 \pm 31.3$ & $141.8 \pm 24.4$ & $136.5 \pm 16.1$ \\
\hline
\end{tabular}

Values are expressed as means \pm SEM $(n=40)$. Values in the same row with different letters in superscript indicate significant differences at $P<0.05$. TC - total cholesterol, TG - triglycerides, Hcy - homocysteine, HOMA-BCF - homeostasis model assessment for $\beta$-cell function, CP - cranberry pomace, HFD - high-fat diet, 3\% UCP-HFD - high-fat diet enriched with $3 \%$ unextruded cranberry pomace, $3 \%$ ECP-HFD - high-fat diet enriched with $3 \%$ extruded cranberry pomace.

ameliorating some metabolic anomalies associated with a high fructose diet.

\section{CONCLUSION}

Cranberry pomace $(\mathrm{CP}$; given in unextruded or extruded form, at dose o $3 \%$ ) was effective in mitigating some of the negative effects of HFD feeding. Both UCP and ECP significantly improved the plasma antioxidant capacity and decreased lipid peroxidation in rats fed an HFD. However, only the addition of 3\% UCP into the HFD significantly increased the faecal lipid excretion and considerably decreased liver index and TG level in rats. The further investigation is needed to determine the role of individual components present in UCP and ECP in the improvement of metabolic conditions observed in the current study.

\section{ACKNOWLEDGEMENTS}

The authors thank Małgorzata Tubacka and Zbyszko Stefański for their assistance during the animal study.

\section{REFERENCES}

Asp, N. G., Johansson, C. G., Hallmer, H., Siljestroem, M. (1983). Rapid enzymatic assay of insoluble and soluble dietary fibre. J. Agric. Food. Chem., 31, 3, 476-482. http://dx.doi.org/10.1021/jf00117a003

Benzie, I. F., Strain, J. J. (1996). The ferric reducing ability of plasma (FRAP) as a measure of 'antioxidant power':
The FRAP assay. Anal. Biochem., 239, 1, 70-76. http:// dx.doi.org/10.1006/abio.1996.0292

Biller, E., Ekielski, A. (2015). Antioxidant activity of aqueous solutions of corn extrudates with the addition of oat flakes. Pol. J. Appl. Sci., 1, 50-55.

Blumberg, J. B., Camesano, T. A., Cassidy, A., Kris-Etherton, P., Howell, A., Manach, C., ..., Vita, J. A. (2013). Cranberries and their bioactive constituents in human health. Adv. Nutr., 4, 6, 618-622. http://dx.doi. org/10.3945/an.113.004473

Buettner, R., Parhofer, K. G., Woenckhaus, M., Wrede, C. E., Kunz-Schughart, L. A., Schölmerich, J., Bollheimer, L. C. (2006). Defining high-fat-diet rat models: Metabolic and molecular effects of different fat types. J. Mol. Endocrinol., 36, 3, 485-501. http://dx.doi.org/10.1677/ jme.1.01909

Chmurzynska, A., Malinowska, A. M., Twardowska-Rajewska, J., Gawecki, J. (2013). Elderly women: homocysteine reduction by short-term folic acid supplementation resulting in increased glucose concentrations and affecting lipid metabolism (C677T MTHFR polymorphism). Nutrition, 29, 6, 841-844. http://dx.doi.org/10.1016/j. nut.2012.09.015

Górnaś, P., Juhņeviča-Radenkova, K., Radenkovs, V., Misina, I., Pugajeva, I., Soliven, A., Seglina, D. (2016). The impact of different baking conditions on the stability of the extractable polyphenols in muffins enriched by strawberry sour cherry raspberry or black currant pomace. LWT - Food. Sci. Technol., 65, 946-653. https:// doi.org/10.1016/j.lwt.2015.09.029

Górnaś, P., Segliņa, D., Lacis, G., Pugajeva, I. (2014a). Dessert and crab apple seeds as a promising and rich source of all four homologues of tocopherol $(\alpha, \beta, \gamma$ and 
Bajerska, J., Chmurzynska, A., Mildner-Szkudlarz, S., Drzymała-Czyż, S., Górnaś, P., Waśkiewicz, A., Muzsik, A., Podgórski, T., Nowaczyk, P., Woźniewicz, M. (2018). Effects of unextruded and extruded cranberry pomace on selected metabolic parameters in high-fat diet fed rats. Acta Sci. Pol. Technol. Aliment., 17(1), 91-100. http://dx.doi.org/10.17306/J.AFS.2018.0542

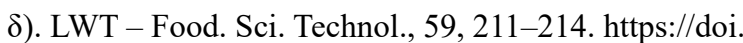
org/10.1016/j.lwt.2014.05.006

Górnaś, P., Siger, A., Czubinski, J., Dwiecki, K., Seglina, D., Nogala-Kalucka, M. (2014b). An alternative RP-HPLC method for the separation and determination of tocopherol and tocotrienol homologues as butter authenticity markers: A comparative study between two European countries. Eur. J. Lipid Sci. Tech., 116, 5, 895-903. http://dx.doi.org/10.1002/ejlt.201300319

Górnaś, P. (2015). Unique variability of tocopherol composition in various seed oils recovered from by-products of apple industry: Rapid and simple determination of all four homologues $(\alpha, \beta, \gamma$ and $\delta$ ) by RP-HPLC/FLD. Food Chem., 172, 129-134. https://doi.org/10.1016/j. foodchem.2014.09.051

Gu, L., House, S. E., Rooney, L. W., Prior, R. L. (2008). Sorghum extrusion increases bioavailability of catechins in weanling pigs. J. Agric. Food Chem., 56, 4, 1283-1288. http://dx.doi.org/10.1021/jf072742i

Hung, H. C., Joshipura, K. J., Jiang, R., Hu, F. B., Hunter, D., Smith-Warner, S. A., ..., Willett, W. C. (2004). Fruit and vegetable intake and risk of major chronic disease. J. Natl. Cancer Inst., 96, 21, 1577-1584. http:// dx.doi.org/10.1093/jnci/djh296

Khanal, R. C., Howard, L. R., Wilkes, S. E., Rogers, T. J., Prior, R. L. (2010). Cranberry pomace partially ameliorates metabolic factors associated with high fructose feeding in growing Sprague-Dawley rats. J. Funct. Foods, 2, 4, 284-291. https://doi.org/10.1016/j.jff.2010.11.003

Kim, M. J., Chung, J. Y., Kim, J. H., Kwak, H. K. (2013). Effects of cranberry powder on biomarkers of oxidative stress and glucose control in $\mathrm{db} / \mathrm{db}$ mice. Nutr. Res. Pract., 7, 6, 430-438. http://dx.doi.org/10.4162/ nrp.2013.7.6.430

Kobayashi, K., Tanaka, T., Okada, S., Morimoto, Y., Matsumura, S., Manio, M. C., ..., Nabeshima, Y. (2016). Hepatocyte beta-Klotho regulates lipid homeostasis but not body weight in mice. FASEB J., 30, 2, 849-862. http://dx.doi.org/10.1096/fj.15-274449

Lattimer, J. M., Haub, M. D. (2010). Effects of dietary fiber and its components on metabolic health. Nutrients, 2, 12, 1266-1289. http://dx.doi.org/10.3390/nu2121266

Makarova, E., Górnaś, P., Konrade, I., Tirzite, D., Cirule, H., Gulbe, A., ..., Dambrova, M. (2015). Acute antihyperglycaemic effects of an unripe apple preparation containing phlorizin in healthy volunteers: A preliminary study. J. Sci. Food Agric., 95, 3, 560-568. http:// dx.doi.org/10.1002/jsfa.6779

Martin-Carron, N., Garcia-Alsonso, A., Goni, I., Saura-Calixto, F. (1997). Nutritional and physiological properties of grape pomace as a potential food ingredient. Am. J. Enol. Vitic., 48, 328-332.

Mildner-Szkudlarz, S., Bajerska, J., Górnaś, P., Seglina, D., Pilarska, A., Jesionowski, T. (2016). Physical and bioactive properties of muffins enriched with raspberry and cranberry pomace powder: A promising application of fruit by-products rich in biocompounds. Plant Foods Hum. Nutr., 71, 2, 165-173. http://dx.doi.org/10.1007/ s11130-016-0539-4

Mildner-Szkudlarz, S., Bajerska, J. (2013). Protective effect of grape by-product-fortified breads against cholesterol/ cholic acid diet-induced hypercholesterolaemia in rats. J. Sci. Food Agric., 93, 13, 3271-3278. http://dx.doi. org/10.1002/jsfa.6171

Mohamed, S. (2014). Functional foods against metabolic syndrome (obesity diabetes hypertension and dyslipidemia) and cardiovascular disease. Trends Food Sci. Technol., 35, 2, 114-128. http://dx.doi.org/10.1016/j. tifs.2013.11.001

Ohkawa, H., Ohishi, N., Yagi, K. (1979). Assay for lipid peroxides in animal tissues by thiobarbituric acid reaction. Anal. Biochem., 95, 2, 351-358. https://doi. org/10.1016/0003-2697(79)90738-3

Pappas, E., Schaich, K. M. (2009). Phytochemicals of cranberries and cranberry products: Characterization, potential health effects, and processing stability. Crit. Rev. Food Sci. Nutr., 49, 9, 741-781. http://dx.doi. org/10.1080/10408390802145377

Qian, J. Y., Ding, X. L. (1996). Effect of twin-screw extrusion on the functional properties of soya fibre. J. Sci. Food Agric., 71, 1, 64-68. http://dx.doi. org/10.1002/(SICI)1097-0010(199605)71:1<64::AIDJSFA536 $>3$.0.CO;2-A

Sharma, P., Gujral, H. S., Singh, B. (2012). Antioxidant activity of barley as affected by extrusion cooking. Food Chem., 131, 4, 1406-1413. https://doi.org/10.1016/j. foodchem.2011.10.009

Singh, S., Gamlath, S., Wakeling, L. (2007). Nutritional aspects of food extrusion: a review. Int. J. Food Sci. Technol., 42, 8, 916-929. http://dx.doi. org/10.1111/j.1365-2621.2006.01309.x

Slavin, J. L., Lloyd, B. (2012). Health benefits of fruits and vegetables. Adv. Nutr., 3, 4, 506-516. http://dx.doi. org/10.3945/an.112.002154

Takahashi, A., Okazaki, Y., Nakamoto, A., Watanabe, S., Sakaguchi, H., Tagashira, Y., ..., Chiji, H. (2014). Dietary anthocyanin-rich Haskap phytochemicals inhibit postprandial hyperlipidemia and hyperglycemia in rats. J. Oleo. Sci., 63, 3, 201-209. https://doi.org/10.5650/ jos.ess 13196 
Bajerska, J., Chmurzynska, A., Mildner-Szkudlarz, S., Drzymała-Czyż, S., Górnaś, P., Waśkiewicz, A., Muzsik, A., Podgórski, T., Nowaczyk, P., Woźniewicz, M. (2018). Effects of unextruded and extruded cranberry pomace on selected metabolic parameters in high-fat diet fed rats. Acta Sci. Pol. Technol. Aliment., 17(1), 91-100. http://dx.doi.org/10.17306/J.AFS.2018.0542

White, B. L., Howard, L. R., Prior, R. L. (2010a). Polyphenolic composition and antioxidant capacity of extruded cranberry pomace. J. Agric. Food Chem., 58, 7, 40374042. http://dx.doi.org/10.1021/jf902838b
White, B. L., Howard, L. R., Prior, R. L. (2010b). Proximate and polyphenolic characterization of cranberry pomace. J. Agric. Food Chem., 58, 7, 4030-4036. http://dx.doi. org/10.1021/jf902829g 